\title{
Australian Journal of

\section{Salt-induced changes in solutes, pigments and essential oil of two basil (Ocimum basilicum L.) genotypes under hydroponic cultivation}

\author{
André Dias de Azevedo Neto*1, Renata Velasques Menezes², Hans Raj Gheyi², Petterson Costa Conceição \\ Silva ${ }^{2}$, Alide Mitsue Watanabe Cova², Rogério Ferreira Ribas ${ }^{2}$, Marcos de Oliveira Ribeiro ${ }^{2}$ \\ ${ }^{1}$ Center of Exact and Technological Sciences, Federal University of Reconcavo of Bahia, Cruz das Almas, Brazil \\ ${ }^{2}$ Center of Agricultural, Environmental and Biological Sciences, Federal University of Reconcavo of Bahia, Cruz das \\ Almas, Brazil
}

*Corresponding author: andre@ufrb.edu.br.com

\begin{abstract}
The aim of this study was to evaluate the effect of salt stress on the contents of inorganic and organic solutes, pigments and essential oil in two basil genotypes cultivated in hydroponic system. The experiment was carried out in a greenhouse. Treatments were distributed in randomized blocks, in a $2 \times 2$ factorial arrangement, corresponding to two contrasting genotypes ('Toscano folha de alface' (TFA) and 'Gennaro de menta' (GM)) and two salt levels ( 0 - control and $80 \mathrm{mM} \mathrm{NaCl}$ ), with six replicates. The $\mathrm{Na}^{+}$, $\mathrm{Cl}^{-}$and $\mathrm{K}^{+}$accumulation in the leaves, stem and roots did not differ between genotypes. Salt stress increased free amino acids accumulation in the leaves of the TFA genotype. The proline content increased in the roots of both genotypes. However, in GM genotype, the proline content $\left(3.12 \mathrm{mmol} \mathrm{g}^{-1} \mathrm{dry}\right.$ mass (DM)) was around 2-fold greater when compared to TFA genotype (1.48 $\left.\mathrm{mmol} \mathrm{g}^{-1} \mathrm{DM}\right)$. The salt stress increased the photosynthetic pigments content only in the GM genotype. Inorganic solutes and photosynthetic pigments content are not good indicators of salt-tolerance in the studied genotypes. Under salt stress, there was increase in oil content in GM genotype, while the TFA genotype showed a decrease compared to control treatment. In spite of showing lower oil content, the TFA genotype showed higher yield and productivity of essential oil compared to GM under salt stress conditions.
\end{abstract}

Keywords: Compatible solutes; inorganic ions; oil productivity; photosynthetic pigments; salinity.

Abbreviations: TFA_Toscano folha de alface'; GM_'Gennaro de menta'; DFT_deep flow technique; DM_dry mass; DAE_days after emergence; NS_nutrient solution; Chla_chlorophyll $a$; Chlb_chlorophyll $b$; Car_carotenoids.

\section{Introduction}

Salinity is one of the main abiotic stresses that limit the growth and productivity of crops. Some studies affirm that the salinity affect around $7 \%$ of the world's land area and $20 \%$ of the irrigated land (Parihar et al., 2015). Saline soils are characterized by excessive salt accumulation in the superficial layers, occurring mainly in arid and semi-arid regions due to edaphoclimatic conditions. Salt stress can negatively affect metabolism and promotes a reduction in the growth of plants. According to Munns (2002), the reduction in productivity in plants under salt stress is due to osmotic and ionic effects. The osmotic effect affects the water availability to the plant, while the ionic effect results in toxicity and nutritional disorders (Dias et al., 2016).

For maintenance of plant growth under salt conditions, without damage to physiological functions, glycophytes need to acclimate to a lower water potential and a higher concentration of salt. This acclimation occurs through the osmotic adjustment, which is characterized by the accumulation of inorganic compounds in the vacuole and compatible organic compounds in the cytoplasm, to avoid biochemical and physiological disorders (Strange, 2004).
During salt stress, organic solutes commonly accumulated are soluble carbohydrates, free amino acids and soluble proteins, being the first two with the greatest contribution to the osmotic potential; therefore, they are featured in studies related with salt stress (Azevedo Neto et al., 2004). The accumulation of organic solutes induced by salinity has some functions in the cytoplasm such as: avoiding damage to enzymatic systems, protecting cellular structures (Munns, 2002) and helping to maintain water absorption by reducing water potential (Strange, 2004).

According to Reyes-Pérez et al. (2013), medicinal and aromatic species have worldwide economic importance due to the continuous and growing demand in the markets. Thus, basil (Ocimum basilicum L.) is indicated as a viable alternative for semi-arid regions of Brazil (Reyes-Pérez et al., 2013), as well as for hydroponic cultivation with low quality water for agriculture (Alves et al., 2015). Basil has aggregated value by its multiple uses: medicinal properties, flavoring and also in the cosmetic and pharmaceutical industries. Basil has a great genotypic diversity and is reported as moderately tolerant to salinity (Barbieri et al., 2012). Thus, the characterization of the responses of basil 
genotypes with different salt-tolerance is fundamental to evaluate the crop potential in saline environment (Bernstein et al., 2010). In a previous study, Menezes et al. (2017) studied the salt-tolerance of six basil genotypes in a DFT hydroponic system after seedling establishment and characterized the 'Gennaro de menta' (GM) and 'Toscano folha de alface' (TFA) genotypes as sensitive and tolerant to salt stress, respectively. These genotypes showed contrasting responses in terms of plant growth and saltinduced leaf injuries.

In addition to the studies related to plant breeding, to improve the tolerance of species to salinity (Kavitha et al., 2012; Gondim Filho et al., 2018), the form of cultivation and management practices can bring benefits for the growth of crops under these conditions. In this context, hydroponic cultivation has been pointed out as a viable technique for the use of brackish waters. Hydroponic agriculture is a strong ally as a mitigating technology against the cultivation in saline soil. Soares et al. (2007) affirm that in this system the responses of plants to salinity may be better than those obtained in soil, considering the greater availability of water. In this study, a comparative analysis is made using two contrasting basil genotypes in order to characterize their responses to salt stress in terms of the content of inorganic and organic solutes, photosynthetic pigments, and content, yield and productivity of essential oil.

\section{Results and discussion}

\section{Effect of salt stress on contents of inorganic solutes}

Salinity increased the sodium content in all parts of the plants of both genotypes (Figure 1). The mean $\mathrm{Na}^{+}$content obtained in the leaves of both genotypes under salt stress was $0.12 \mathrm{mmol} \mathrm{g}^{-1} \mathrm{DM}$. In the stem and roots, these means were respectively 1.15 and $1.32 \mathrm{mmol} \mathrm{g}^{-1} \mathrm{DM}$ for TFA and 1.32 and $1.37 \mathrm{mmol} \mathrm{g}^{-1} \mathrm{DM}$ for GM. Thus, the data show that, in the treatment of $80 \mathrm{mM} \mathrm{NaCl}$, the sodium concentration in the stem and roots was about 10 -fold higher than in the leaves.

The higher $\mathrm{Na}^{+}$accumulation in stem and root tissues may be related to plant's ability to restrict the transport of this ions from the roots to the leaves, and to maintain a low $\mathrm{Na}^{+}$ content in leaf tissue, which may indicate a mechanism of salinity tolerance (Ning et al., 2015), as observed in Fig. 1. However, the $\mathrm{Na}^{+}$partition between the organs of plants in both genotypes showed no relationship with tolerance or sensitivity to salt stress, since the $\mathrm{Na}^{+}$concentration in all parts of the plants was similar in both genotypes. Furthermore, $\mathrm{Na}^{+}$content in different parts did not vary with the age of the plant except for the stem in the GM which 32 days showed higher levels (1.64 $\left.\mathrm{mmol} \mathrm{g}^{-1} \mathrm{DM}\right)$.

Similar to that observed for $\mathrm{Na}^{+}$, salinity increased the $\mathrm{Cl}^{-}$ content in all organs of both genotypes (Figure 2). However, contrary to the $\mathrm{Na}^{+}$content in the salt treatment, which remained relatively stable, the $\mathrm{Cl}^{-}$content increased with the duration of exposure to salt stress.

For all parts of plants, the $\mathrm{Cl}^{-}$contents under the salt treatment were similar between genotypes. The mean contents obtained in the leaves were $0.67 \mathrm{mmol} \mathrm{g}^{-1} \mathrm{DM}$ (TFA) and $0.56 \mathrm{mmol} \mathrm{g}^{-1} \mathrm{DM}$ (GM), in the stem were 0.56 $\mathrm{mmol} \mathrm{g}^{-1} \mathrm{DM}$ (TFA) and $50 \mathrm{mmol} \mathrm{g}^{-1} \mathrm{DM}$ (GM), and in the roots were $0.53 \mathrm{mmol} \mathrm{g}^{-1} \mathrm{DM}$ (TFA) and $0.47 \mathrm{mmol} \mathrm{g}^{-1} \mathrm{DM}$ (GM).

It can be observed that, when compared to $\mathrm{Na}^{+}$, the uptake and transport of $\mathrm{Cl}^{-}$to shoot seems to be less controlled, since the $\mathrm{Cl}^{-}$was distributed in a similar way among the plant organs. Ning et al. (2015) also found similar results for basil and reported that the non-restriction of $\mathrm{Cl}^{-}$to shoot may be linked to mechanisms related to $\mathrm{NaCl}$ toxicity. Compared with $\mathrm{Na}^{+}$, the more pronounced accumulation of $\mathrm{Cl}^{-}$in the leaves suggests a higher participation of this ion for the osmotic adjustment in this organ.

It is observed that under salt stress, the $\mathrm{K}^{+}$content in both genotypes was increased in the leaf and decreased in the stem and root (Figure 3 ). In roots, the $\mathrm{NaCl}$-induced decrease in $\mathrm{K}^{+}$content was more pronounced at 8 and 16 days in both TFA (65\%) and GM (77\%) genotypes. It was also observed that in the salt stress treatment, the mean $\mathrm{K}^{+}$ content in the leaf did not vary until 24 days of cultivation, for both genotypes. However, at 32 days of cultivation, $\mathrm{K}^{+}$ content increased by $37 \%$ in the TFA and decreased $17 \%$ in $\mathrm{GM}$. Thus, the $\mathrm{K}^{+}$content at 32 days in TFA $\left(2.65 \mathrm{mmol} \mathrm{g}^{-1}\right.$ DM) was $47 \%$ higher than that of GM $\left(1.80 \mathrm{mmol} \mathrm{g}^{-1} \mathrm{DM}\right)$.

The salt-induced reduction of $\mathrm{K}^{+}$content only occurred in the stem and root, corroborating the results of Ferreira-Silva et al. (2008). Although $\mathrm{K}^{+}$content in the leaves of both genotypes remained above normal levels (control treatment), at the end of the experimental period the increase in the $\mathrm{K}^{+}$content in TFA suggests a better maintenance in the osmotic and physiological regulation of this genotype, in relation to the GM. It can be considered that, among the inorganic solutes accumulated in the leaves, $\mathrm{Cl}^{-}$and $\mathrm{K}^{+}$are the ions of greater contribution to the osmotic adjustment in the basil.

\section{Effect of salt stress on contents of organics solutes}

It was observed that the salinity did not affect the soluble carbohydrate content in leaves and roots of TFA genotype (Figures $4 \mathrm{~A}$ and $4 \mathrm{C}$ ). However, in GM genotype, the salt stress increased on average $42 \%$ the leaf carbohydrate content when compared to control, but did not affect these solutes in the roots (Figures $4 B$ and $4 D$ ). The free amino acid content in leaf and root of TFA genotype in the different period were respectively, on average 57 and $29 \%$ higher than the control (Figures $4 \mathrm{E}$ and $4 \mathrm{G}$ ). However, in leaf and root of GM the free amino acid content was not affected by salt stress (Figures $4 \mathrm{~F}$ and $4 \mathrm{H}$ ), except at $32 \mathrm{DAE}$ in root.

The organic solutes are important molecules related to the survival of the glycophytes species under salt conditions, being considered important physiological markers (Azevedo Neto et al., 2004). The accumulation of amino acids and soluble carbohydrates often presents a greater contribution to the osmotic potential when compared to the other compatible organic solutes (Silva et al., 2009). However, in this study, a higher increase of free amino acids suggests a greater relative importance of this solute. Considering that the free amino acids content increased significantly only in TFA genotype (salt-tolerant), these results suggest that the increase of the free amino acids content in the leaves and roots is related to the salt-tolerance in basil.

Regarding the soluble proteins, no substantial changes were observed in both genotypes when the control and salt stress treatments were compared (Figures 5A-5D). In this way the 
Table 1. Composition* of standard nutrient solution of Furlani (1998) utilized in the study.

\begin{tabular}{|c|c|}
\hline Fertilizers & ---------- g 1000L-1_--------- \\
\hline Calcium nitrate dihydrate & 750 \\
\hline Potassium nitrate & 500 \\
\hline Mono ammonium phosphate & 150 \\
\hline Magnesium sulphate & 400 \\
\hline Copper sulphate & 0.15 \\
\hline Zinc sulphate & 0.3 \\
\hline Manganese sulphate & 1.5 \\
\hline Boric acid & 1.8 \\
\hline Sodium molybedate & 0.15 \\
\hline Tenso-Fe (FeEDDHMA 6\%) & 34.67 \\
\hline
\end{tabular}

Tenso-Fe (FeEDDHMA 6\%)

34.67

* Concentration of nutrients $\left(\mathrm{mg} \mathrm{L}^{-1}\right): \mathrm{N}-\mathrm{NH}_{4}=24 ; \mathrm{N}^{-N_{3}}{ }_{3}=173.75 ; \mathrm{P}=39 ; \mathrm{K}=182.5 ; \mathrm{Ca}=142.5 ; \mathrm{Mg}=40 ; \mathrm{S}=52 ; \mathrm{B}=0.255 ; \mathrm{Cu}=0.0195 ; \mathrm{Fe}=1.79 ; \mathrm{Mn}=0.39 ; \mathrm{Mo}=0.0585 ; \mathrm{Zn}=0.066$.

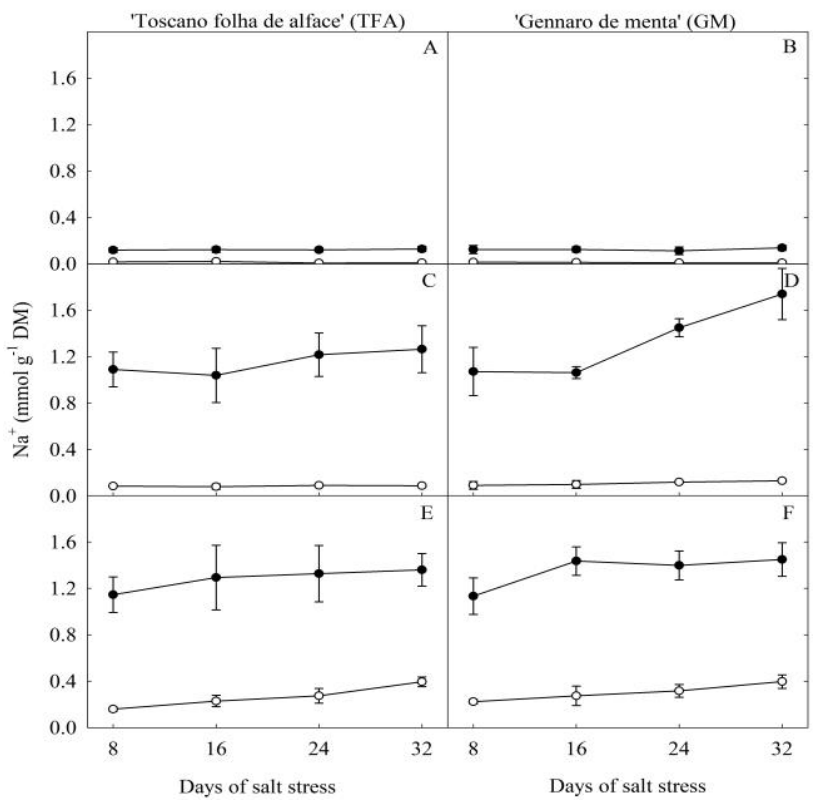

Fig 1. $\mathrm{Na}^{+}$content in leaves $(A, B)$, stem $(C, D)$ and roots $(E, F)$ in two basil genotypes cultivated for 32 days in a hydroponic system under control conditions $(\bigcirc)$ or presence of $80 \mathrm{mM} \mathrm{NaCl}(\Theta)$ in the nutrient solution. The dots indicate the means of six replicates and the bars the standard deviations.

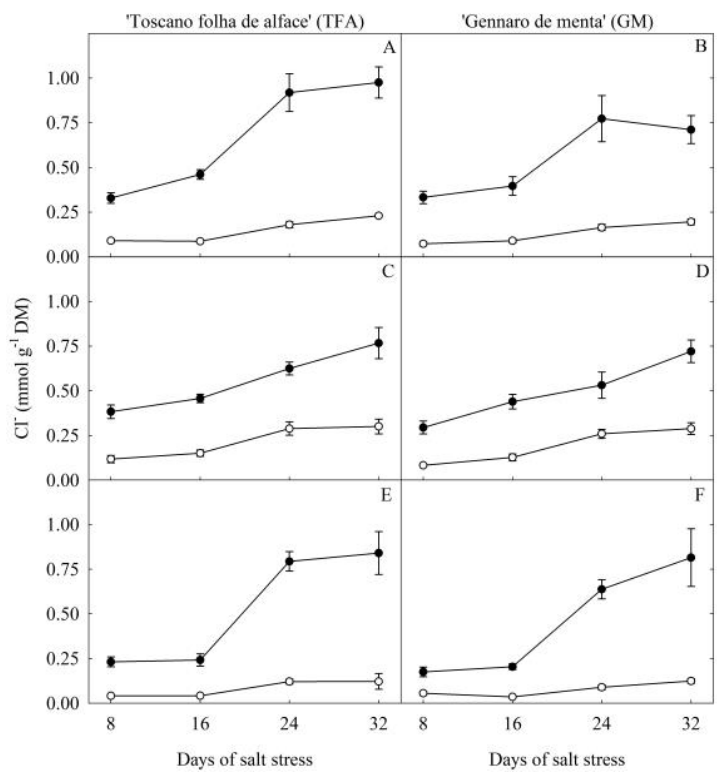

Fig 2. Cl- content in leaves (A, B), stem (C, D) and roots (E, F) in two basil genotypes cultivated for 32 days in a hydroponic system under control conditions $(O)$ or presence of $80 \mathrm{mM} \mathrm{NaCl}(\Theta)$ in the nutrient solution. The dots indicate the means of six replicates and the bars the standard deviations. 


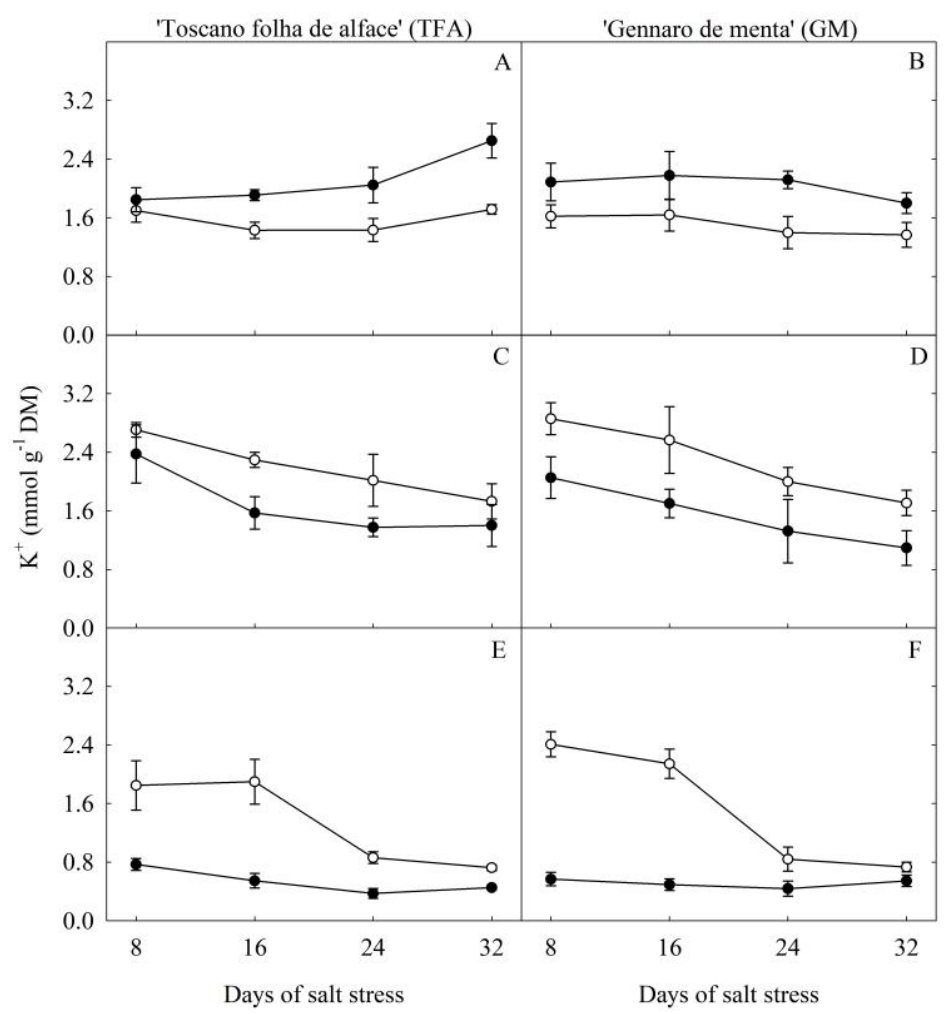

Fig 3. $\mathrm{K}^{+}$content in leaves $(\mathrm{A}, \mathrm{B})$, stem $(\mathrm{C}, \mathrm{D})$ and roots $(\mathrm{E}, \mathrm{F})$ in two basil genotypes cultivated for 32 days in hydroponic system under control conditions $(O)$ or presence of $80 \mathrm{mM} \mathrm{NaCl}(\mathbf{O})$ in the nutrient solution. The dots indicate the means of six replicates and the bars the standard deviations.

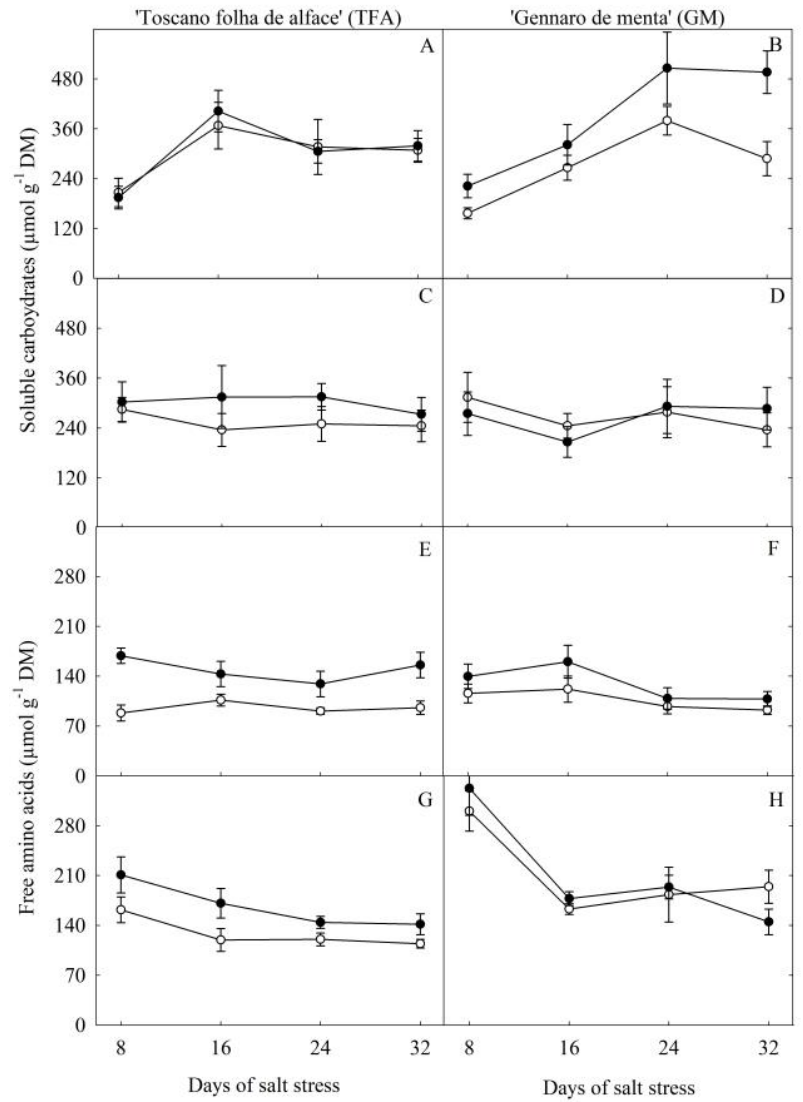

Fig 4. Soluble carbohydrate and free amino acids content in leaves $(A, B, E$ and $F)$ and roots $(B, C, G$ and $H)$ in two basil genotypes cultivated for 32 days in hydroponic system under control conditions $(O)$ or presence of $80 \mathrm{mM} \mathrm{NaCl}(O)$ in the nutrient solution. The dots indicate the means of six replicates and the bars the standard deviations. 


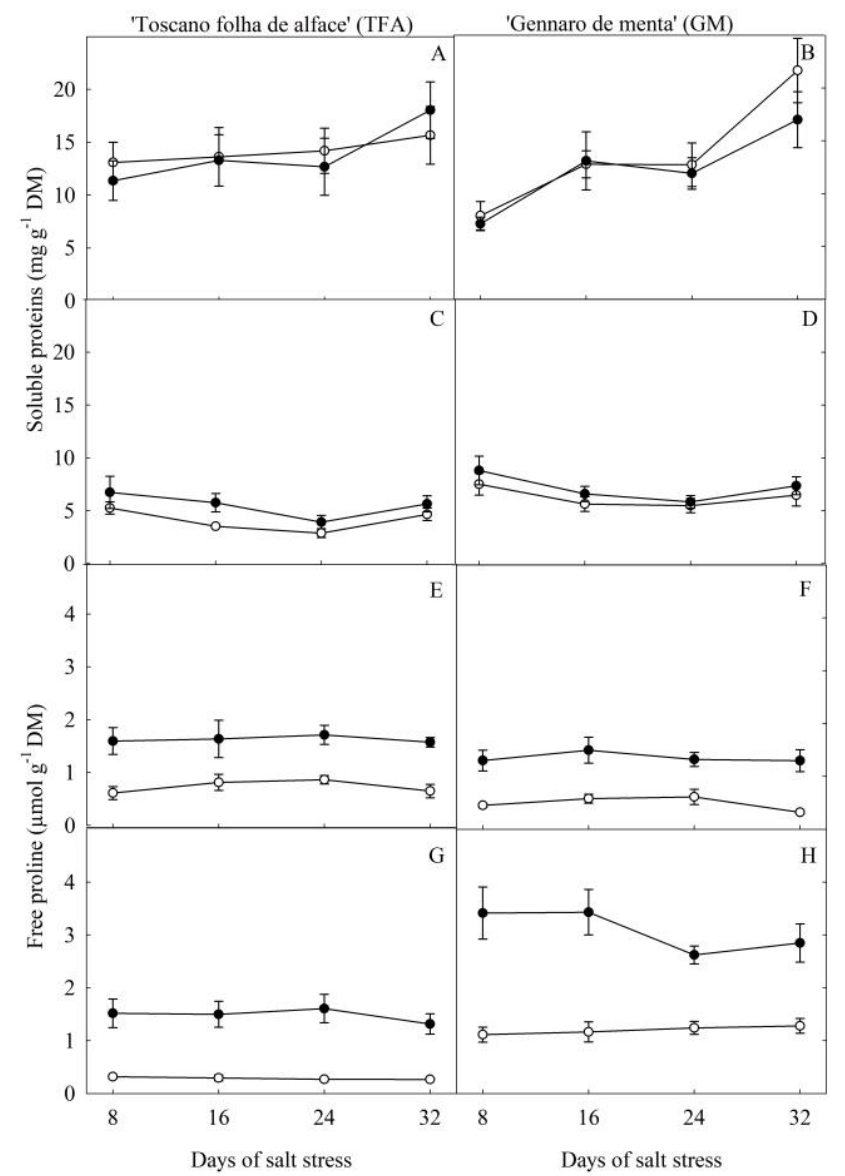

Fig 5. Soluble protein and free proline content in leaves $(A, B, E, F)$ and roots $(C, D, G, H)$ in two basil genotypes cultivated for 32 days in hydroponic system under control conditions $(O)$ or presence of $80 \mathrm{mM} \mathrm{NaCl}(\mathbf{)})$ in the nutrient solution. The dots indicate the means of six replicates and the bars the standard deviations.

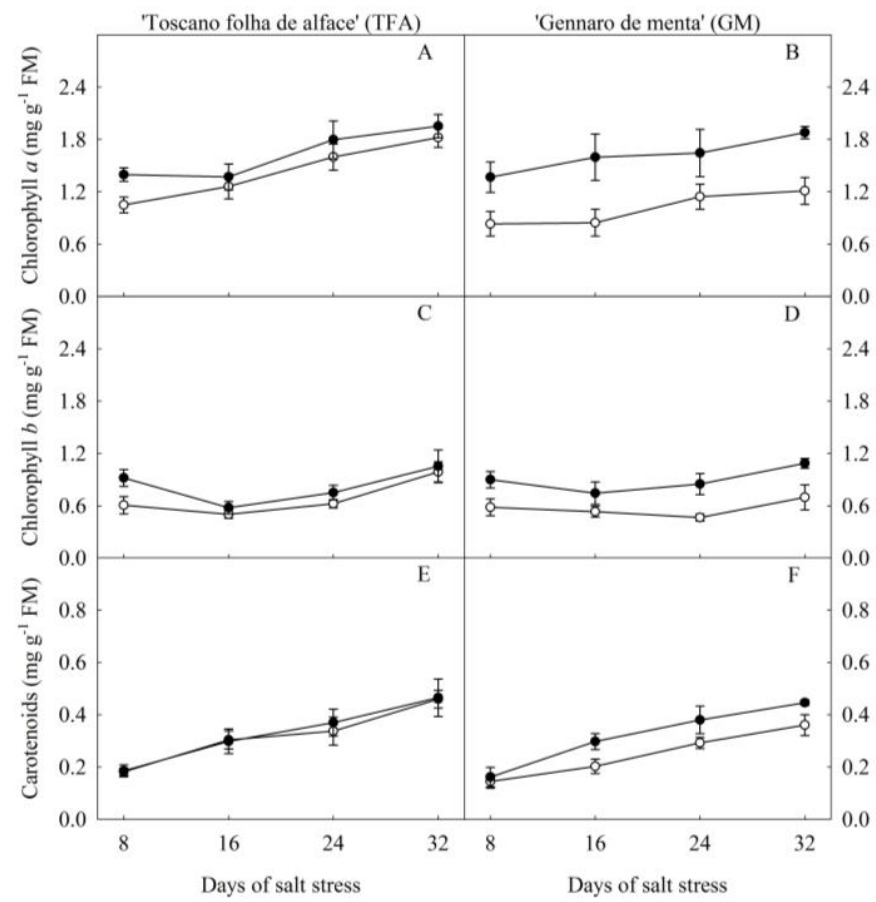

Fig 6. Chlorophyll $a$ - Chla (A, B), chlorophyll $b$ - Chlb (C, D) and carotenoids - Car (E, F) content of two basil genotypes cultivated for 32 days in a hydroponic system under control conditions $(O)$ or presence of $80 \mathrm{mM} \mathrm{NaCl}(O)$ in the nutrient solution. The dots indicate the means of six replicates and the bars the standard deviations. 


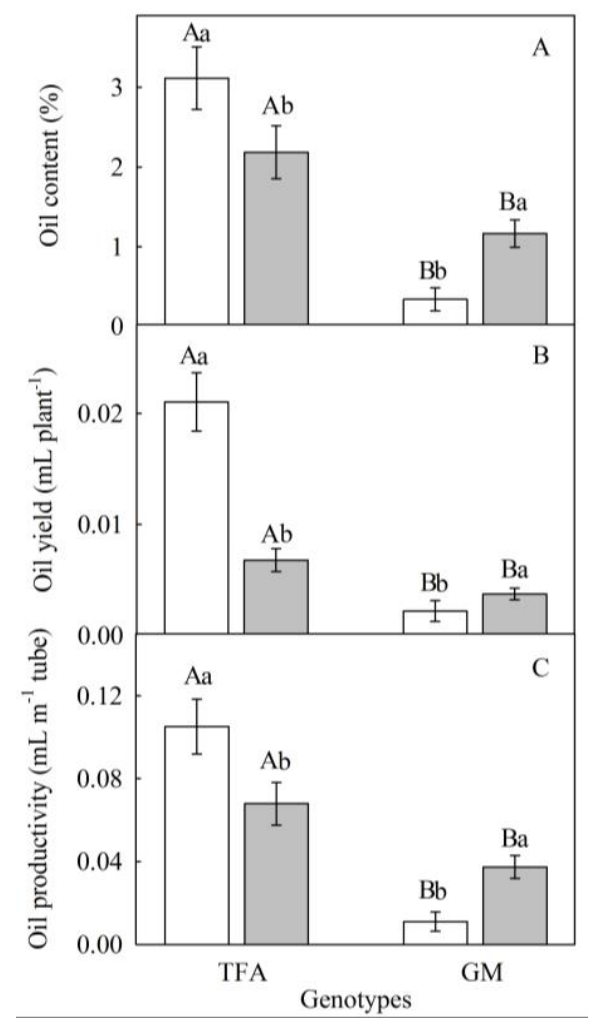

Fig 7. Oil content (A), oil yield (B) and oil productivity (C) in two basil genotypes cultivated for 32 days in a hydroponic system under control conditions $(\square)$ or $80 \mathrm{mM} \mathrm{NaCl}(\boldsymbol{\square})$ in the nutrient solution. Means followed by different small letters (in each genotype) and different capital letters (between genotypes in the same treatment) are statistically different ( $\leq \leq 0.05)$, according to Tukey's test. Vertical lines in the bars indicate the standard deviations of six replicates.

accumulation of soluble proteins showed no relation with basil tolerance or sensitivity to salt stress. Salinity increased the free proline content in leaves and roots of the two genotypes (Figures $5 \mathrm{E}-5 \mathrm{H}$ ). In leaves, mean free proline concentrations in salt treatment were similar, $1.63 \mathrm{mmol} \mathrm{g}^{-1}$ DM (TFA) and $1.35 \mathrm{mmol} \mathrm{g}^{-1} \mathrm{DM}$ (GM). However, in roots the GM genotype ( $\left.3.12 \mathrm{mmol} \mathrm{g}^{-1} \mathrm{DM}\right)$ had twice the free proline when compared to the TFA ( $\left.1.48 \mathrm{mmol} \mathrm{g}^{-1} \mathrm{DM}\right)$.

According to lqbal et al. (2014), the proline accumulation is one of the mechanisms used by plants to mitigate the effects of salt stress. However, other authors argue that the proline accumulation is insufficient to promote the osmotic adjustment. According to Cova et al. (2016), the quantitative contribution of proline to osmotic adjustment in noni (Morinda citrifolia L.) was not significant. These authors suggest that the salt-induced increase in proline concentrations plays another role in salt stress acclimation or is an indicator of salt-induced metabolic disturbances. In the present study, in spite of the higher proline content in GM roots, the significant increase of proline in stressed leaves and roots of both genotypes seems to be related to its role as a signalling molecule of salt stress damage, as suggested by Cova et al. (2016). From the point of view of osmotic adjustment, the concentrations of soluble carbohydrates and free amino acids were quantitatively much higher than that of proline, corroborating with Oliveira et al. (2013), who consider that proline levels are not sufficient for a significant contribution in the osmotic adjustment. Lacerda et al. (2003), consider that the accumulation of osmolytes, especially proline, did not seem to be related to salt-tolerance in sorghum, but to a consequence of tissue dehydration.

\section{Effect of salt stress on photosynthetic pigments}

Salinity did not change content of the photosynthetic pigments in the TFA genotype (Figures $6 \mathrm{~A}, 6 \mathrm{C}$ and $6 \mathrm{E}$ ), but induced a mean increase in the Chla (64\%), Chlb (58\%) and Car (34\%) content in GM genotype (Figures 6B, 6D and 6F). Considering that the content of pigments was not changed in TFA (salt-tolerant genotype) and increased in GM (saltsensitive genotype), the results suggest that the variation of the pigments content is not a good indicator for the salttolerance in basil. Bernstein et al. (2010) also observed that the concentrations of Chla and $\mathrm{Chl} b$ in basil were not significantly altered by salinity.

As observed in the GM genotype the salt-induced increase in chlorophyll content was also reported in Ananas porteanus (Mendes et al., 2011). The authors associated this increase to the activation of the photosynthetic apparatus protection mechanism, by increasing the size or number of chloroplasts.

Under salt stress, plants present different responses to the carotenoids accumulation (Mane et al., 2010), which are photoprotective pigments integrated into the membranes (Taibi et al., 2016). In addition, carotenoids are also involved in the defence mechanisms against oxidative stress (Bernstein et al., 2010; Taibi et al., 2016). Thus, the increase of carotenoids in stressed plants of salt-sensitive genotype (GM) suggests a greater need to dissipate excess light energy, and to remove reactive oxygen species.

As the increase of the chlorophyll and carotenoid contents was only observed in the genotype that presented the highest biomass reduction, the data suggest that this increase may be the result of a concentration effect. On the 
other hand, the higher reduction of the growth of this genotype may, at least in part, be explained by the higher energy cost in the pigment biosynthesis for the photosynthesis maintenance and photosynthetic apparatus protection.

\section{Effect of salt stress on content and productivity of essential oil}

Salt stress reduced by $30 \%$ the essential oil content in the TFA genotype, but it increased $244 \%$ in GM (Figure $7 A$ ). Consequently, the yield and productivity decreased, respectively, 68 and 35\% in TFA and increased 70 and $240 \%$ in GM (Figures 7B and 7C). However, oil content of the TFA genotype was 9 and 2-fold higher than GM genotypes, in the control and salt conditions, respectively. In aromatic plants the production and biosynthesis of secondary metabolites are strongly influenced by biotic and abiotic stresses (Çoban and Baydar, 2016). Under salt conditions, the essential oil content in plants may decrease (Khorasaninejad et al., 2010), increase (Bernstein et al., 2010) or not change (Ragagnin et al., 2014), depending on the species studied. It has been reported that the increase in oil content is commonly followed by restriction of biomass production (Valifard et al., 2014; Rebey et al., 2017). Bernstein et al. (2010), relate the increase in oil production with considerable reductions in biomass, that is, for these authors the increase in oil content is not necessarily a stimulus of its biosynthesis, but a concentration effect. However, the data suggest that in the GM, the increase in essential oil content under stress conditions is related to the biosynthesis stimulation, since the increase in the essential oil content (244\%) was much higher than the dry mass reduction (61\%), which cannot be explained only by the concentration effect. In contrast to $\mathrm{GM}$, the reduction in oil content in TFA genotype associated with no change in leaf biomass indicates that salt stress reduced oil biosynthesis in this genotype. Even with the reduction of the essential oil content in TFA, the oil productivity of this genotype $(0.0679$ $\mathrm{mL} \mathrm{m}^{-1}$ tube) was $82 \%$ higher than that of $\mathrm{GM}\left(0.0374 \mathrm{~mL} \mathrm{~m}^{-}\right.$ 1 tube). The essential oil content is a variable that can affect the economic value of this crop, because it is directly related to yield and productivity. In this study, although the salinity increases the productivity of the GM genotype and decreases that of TFA, from the economic point of view, the TFA showed to be most indicated than the GM for hydroponic production with brackish waters as for as oil production is concerned.Another important aspect to consider is the intensity of stress on oil production. As an example, Valifard et al. (2014), demonstrated that the essential oil content in Salvia mirzayanii varies according to salinity in the root environment. As the essential oil content in our study was evaluated only at two $\mathrm{NaCl}$ concentrations ( 0 and $80 \mathrm{mM})$, further studies are required to identify the salinity level capable of inducing maximum oil yield, mainly in TFA genotype.

\section{Materials and methods}

\section{Location, experimental procedure and treatments}

The experiment was carried out in a greenhouse of the graduate Program in Agricultural Engineering, at the Federal
University of Reconcavo of Bahia, in Cruz das Almas-BA, Brazil (1240'19"S, 396'23"W). The experiment was carried in a hydroponic system type DFT (Deep Flow Technique) adapted in PVC tubes. The seedlings were prepared from seeds obtained from Isla Sementes $L t d a{ }^{\circledR}$. The genotypes 'Toscano folha de alface' (TFA) and 'Gennaro de menta' (GM), were classified as salt-tolerant and salt-sensitive in a preliminary experiment (Menezes et al., 2017) in which, it was found that $80 \mathrm{mM} \mathrm{NaCl}$ did not affect the biomass production of the leaves of the TFA, but decreased it by $61 \%$ in case of GM. The experimental design was a randomized block in factorial arrangement with 2 (genotypes) $\times 2$ (salt levels), and six replications, each consisting of 12 plants.

The seeds were sown in $150 \mathrm{~mL}$ plastic cups containing washed coconut fiber, irrigated daily with water from the local supply company. At 19 days after emergence (DAE), with the second pair of leaves fully expanded, the seedlings were transferred to the DFT hydroponic cultivation system (Menezes et al., 2017), with plant spacing of $0.20 \mathrm{~m}$.

The nutrient solution (NS) of Furlani (1998), specific for leafy vegetables (Table 1), was used for the cultivation. After 2 days of acclimation, the seedlings received respective salt treatments $(0$ - control or $80 \mathrm{mM} \mathrm{NaCl})$. $\mathrm{NaCl}$ was gradually added, $40 \mathrm{mM}$ per day-1, to avoid osmotic shock. The electrical conductivities of the NS were $2.0 \mathrm{dS} \mathrm{m}^{-1}$ and $10 \mathrm{dS}$ $\mathrm{m}^{-1}$, respectively, for the non-salt and salt treatment. Renewal of NS was performed every 10 days to avoid changes in electrical conductivities and $\mathrm{NaCl}$ concentrations. The $\mathrm{pH}$ was monitored daily and maintained at $6.0 \pm 0.5$ with the addition of $\mathrm{NaOH}$ or $\mathrm{HCl}$. The aeration of the NS was performed through recirculation, every three hours, for $0.5 \mathrm{~h}$ and triggered by digital timer.

Plants were grown in deep flow technique (DFT) adapted in 6-m-long PVC tubes in a low cost hydroponic system type pyramid (Santos Júnior et al., 2016). Each treatment consisted of a plastic tank to store the nutrient solution in the absence or presence of $80 \mathrm{mM}$ of $\mathrm{NaCl}$.

\section{Determination of contents of norganic and organic solutes}

Plants were grown over a 32 days period (54 DAE). The beginning of flowering for salt stress treatment was considered the end of the experimental period. Four harvests were performed during the experimental period at $8,16,24$ and 32 days after stress application. Two plants per treatment were used in each harvest. The plants were separated into leaves, stems and roots, and dried in an oven with air circulation at $45^{\circ} \mathrm{C}$ for $72 \mathrm{~h}$.

For determination of contents of sodium $\left(\mathrm{Na}^{+}\right)$, potassium $\left(\mathrm{K}^{+}\right)$, and chloride $\left(\mathrm{Cl}^{-}\right)$extracts of plant material were prepared according to the methodologies described by Cova et al. (2016).

The preparation of extracts and the determination of soluble carbohydrates, free amino acids, soluble proteins, and free proline were carried out as described by Sacramento et al. (2014).

\section{Determination of contents of photosynthetic pigments}

Chlorophyll $a$ (Chla), chlorophyll $b$ (Chlb), and carotenoids (Car) content was determined in a spectrophotometer at 649,664 , and $470 \mathrm{~nm}$. Ethanolic extracts were prepared 
according to the methodology recommended by Lichtenthaler and Buschmann (2001).

\section{Extraction and quantification of essential oil}

Extraction of essential oil was carried out by hydrodistillation in the Clevenger apparatus, using $16 \mathrm{~g}$ of dried $\left(45^{\circ} \mathrm{C}\right)$ basil leaves. Preliminary tests with the samples showed that the stem of basil does not contain essential oil. The extraction process was carried out for $2 \mathrm{~h}$, counted from the condensation of the first drop, and the volume of oil extracted was measured in the graduated Clevenger column. From the volume of essential oil collected, the content, yield and productivity of the essential oil were calculated. The percentage oil content was calculated according to Zenebon et al. (2008). The oil yield plant ${ }^{-1}$ was calculated by multiplying the essential oil content (\%) and the total leaf dry mass, divided by 100 . To calculate the oil productivity $\mathrm{m}^{-}$ 1 hydroponic channel (tube), the oil yield plant ${ }^{-1}$ was multiplied by the number of plants per linear meter of tube.

\section{Statistical analysis}

The results of the masses, organic and inorganic solutes contents and pigments were submitted to analysis of variance ( $F$ test) and the mean values were compared by their respective standard deviations, according to Snedecor (1956). For the essential oil content, the results were submitted to analysis of variance and the means were compared by Tukey's multiple range test at 0.05 probability using the software SISVAR 4.6 (Ferreira, 2011).

\section{Conclusions}

Inorganic solutes content $\left(\mathrm{Na}^{+}, \mathrm{Cl}^{-}\right.$and $\left.\mathrm{K}^{+}\right)$are not good indicators of salt-tolerance in the studied basil genotypes. Among the organic solutes, the increase of the free amino acids content in the leaves and roots is related to the salttolerance in basil. The variation of the photosynthetic pigments is not related to salt-tolerance or salt sensitivity in the studied genotypes. The salinity of $80 \mathrm{mM} \mathrm{NaCl}$ induces essential oil biosynthesis in the 'Gennaro de menta' (GM) genotype and inhibits in the 'Toscano folha de alface (TFA), however the TFA shows higher productivity and is the most suitable for oil production in hydroponic cultivation at this salt level.

\section{Acknowledgements}

We thank the 'Coordenação de Aperfeiçoamento de Pessoal de Nível Superior (CAPES)', the 'Conselho Nacional de Desenvolvimento Científico e Tecnológico' (CNPq), 'Fundação de Amparo à Pesquisa do Estado da Bahia (FAPESB)' and the Universidade Federal do Recôncavo da Bahia (UFRB) for financial support to conduct this study.

\section{References}

Alves, LS, Paz VPS, Silva, AJP, Oliveira GXS, Oliveira FER, Amorim EL (2015) Teor, rendimento e composição química do óleo essencial de plantas de manjericão submetidas ao estresse salino com NaCl. Rev Bras PI Med. 17:807-813.
Azevedo Neto AD, Prisco JT, Enéas Filho J, Lacerda CF, Silva JV, Costa PHA, Gomes Filho E (2004) Effects of salt stress on plant growth, stomatal response and solute accumulation of different maize genotypes. Rev Bras Fisiol Veg. 16:31-38.

Barbieri G, Vallone S, Orsini F, Paradiso R, Pascale S, Negrezakharov F, Maggio A (2012) Stomatal density and metabolic determinants mediate salt stress adaptation and water use efficiency in basil (Ocimum basilicum L.). J Plant Physiol. 169:1737-1746.

Bernstein N, Kravchik M, Dudai N (2010) Salinity-induced changes in essential oil, pigments and salts accumulation in sweet basil (Ocimum basilicum) in relation to alterations of morphological development. Ann Appl Biol. 156:167177.

Çoban O, Baydar NG (2016) Brassinosteroid effects on some physical and biochemical properties and secondary metabolite accumulation in peppermint (Mentha piperita L) under salt stress. Ind Crops Prod. 86:251-258.

Cova AMW, Azevedo Neto AD, Ribas RF, Gheyi HR, Menezes RV (2016) Inorganic solute accumulation in noni (Morinda citrifolia L.) under salt stress during initial growth. Afr J Agric Res. 11:3347-3354.

Dias NS, Blanco FF, Souza ER, Ferreira JFS, Sousa Neto ON, Queiroz ISR (2016) Efeitos dos sais na planta e tolerância das culturas à salinidade. In: Gheyi HR, Dias NS, Lacerda CF, Gomes Filho E (eds) Manejo da salinidade na agricultura: estudos básicos e aplicados, 2nd edn. INCTSal, Fortaleza. 11.

Ferreira DF (2011) Sisvar: a computer statistical analysis system. Ciên Agrotec. 35:1039-1042.

Ferreira-Silva SL, Silveira JAG, Voigt EL, Soares LSP, Viégas RA (2008) Changes in physiological indicators associated with salt tolerance in two contrasting cashew rootstocks. Braz J Plant Physiol. 20:51-59.

Furlani PR (1998) Instruções para o cultivo de hortaliças de folhas pela técnica de hidroponia - NFT. Campinas: IAC. 30p. Boletim técnico, 168.

Gondim Filho H, Silva PCC, Silva MG, Pereira MM, Soares TM, Azevedo Neto AD, Vasconcelos RS, Gheyi HR (2018) Growth, production and essential oil content of basil genotypes in hydroponic conditions under salt stress. J Exp Agric Inter. 25:1-10.

Iqbal N, Umar S, Khan NA, Khan MIR (2014) A new perspective of phytohormones in salinity tolerance: regulation of proline metabolism. Env Exp Bot. 100:34-42.

Kavitha PG, Miller AJ, Mathew MK, Maathuis FJM (2012) Rice cultivars with differing salt tolerance contain similar cation channels in their root cells. J Exp Bot. 63:3289-3296.

Khorasaninejad S, Mousavi A, Soltanloo H, Hemmati K, Khalighi A (2010) The effect of salinity stress on growth parameters essential oil yield and constituent of peppermint (Mentha piperita L.). World Appl Sci J. 11:1403-1407.

Lacerda CF, Cambraia J, Oliva MA, Ruiz HA, Prisco JT (2003) Solute accumulation and distribution during shoot and leaf development in two sorghum genotypes under salt stress. Env Exp Bot. 49:107-120.

Lichtenthaler HK, Buschmann C (2001) Chlorophylls and carotenoids: measurement and characterization by UV-VIS spectroscopy. Curr Prot Food Anal Chem 1:431-438. 
Mane AV, Karadge BA, Samant JS (2010) Salinity induced changes in photosynthetic pigments and polyphenols of Cymbopogon nardus (L.) Rendle. J Chem Pharma Res. 2:338-347.

Mendes BSS, Willadino L, Cunha PC, Oliveira Filho RA, Camara TR (2011) Mecanismo fisiológicos e bioquímicos do abacaxi ornamental sob estresse salino. Rev Caatinga. 24:71-77.

Menezes RV, Azevedo Neto AD, Gheyi HR, Cova AMW, Silva HHB (2017) Tolerance of basil genotypes to salinity. J Agric Sci. 9:283-295.

Munns R (2002) Physiology of salt and water stress. Plant Cell Env. 25:239-250.

Ning JF, Cui LH, Yang SH, Ai SY, Li MJ, Sun LL, Chen Y, Wang $\mathrm{RH}$, Zeng ZB (2015) Basil ionic responses to seawater stress and the identification of gland salt secretion. J Anim Plant Sci. 25:131-138.

Oliveira VP, Marques EC, Lacerda CF, Prisco JT, Gomes-Filho E (2013) Physiological and biochemical characteristics of Sorghum bicolor and Sorghum sudanense subjected to salt stress in two stages of development. Afr J Agric Res. 8:660670.

Parihar $P$, Singh $S$, Singh R, Singh VP, Prasad SM (2015) Effect of salinity stress on plants and its tolerance strategies: $A$ review. Environ Sci Pollut Res. 22:4056-4075.

Ragagnin RCG, Albuquerque CC, Oliveira FFM, Santos RG, Gurgel EP, Diniz JC, Rocha SAS, Viana FA (2014) Effect of salt stress on the growth of Lippia gracilis Schauer and on the quality of its essential oil. Acta Bot Bras. 28:346-351.

Rebey IB, Bourgou S, Rahali FZ, Msaada K, Ksouri R, Marzouk B (2017) Relation between salt tolerance and biochemical changes in cumin (Cuminum cyminum L.) seeds. J Food Drug Anal. 25:391-402.

Reyes-Pérez F, Salazar-Garcia MG, Romero-Baranzini AL, Islas-Rubio AR (2013) Ramirez-Wong B Estimated glycemic index and dietary fibre content of cookies elaborated with extruded wheat bran. Plant Foods Hum Nutr. 68:52-56.
Sacramento BL, Cruz TS, Silva LL, Mota KNAB, Azevedo Neto $A D$ (2014) Pigmentos e teores de solutos orgânicos em plantas de aguapé sob estresse salino. Enc Biosf. 10:33-44.

Santos Júnior JA, Gheyi HR, Cavalcante AR, Francilino AH, Perez-Marin AM (2016) Crescimento de girassóis ornamentais sob estresse salino em hidroponia de baixo custo. Irriga. 21:591-604.

Silva EN, Silveira JAG, Rodrigues CRF, Lima CS, Viégas RA (2009) Contribuição de solutos orgânicos e inorgânicos no ajustamento osmótico de pinhão-manso submetido à salinidade. Pesq Agropec Bras. 44:437-445.

Snedecor GW (1956) Statistical methods applied to experiments in agriculture and biology. 5th edn. lowa State University Press, Ames.

Soares TM, Silva EFF, Duarte SN, Melo RF, Jorge CA, BonfimSilva EM (2007) Produção de alface utilizando águas salinas em sistema hidropônico. Irriga. 12:235-248.

Strange K (2004) Cellular volume homeostasis. Adv Physiol Educ. 28:155-159.

Taibi K, Taibi F, Abderrahim LA, Ennajah A, Belkhodja M, Mulet JM (2016) Effect of salt stress on growth chlorophyll content lipid peroxidation and antioxidant defence systems in Phaseolus vulgaris L. S Afr J Bot. 105:306-312.

Valifard $M$, Mohsenzadeh S, Kholdebarin B, Rowshan V (2014) Effects of salt stress on volatile compounds total phenolic content and antioxidant activities of Salvia mirzayanii. S Afr J Bot. 93:92-97.

Zenebon O, Pascuet NS, Tiglea P (2008) Métodos físicoquímicos para análise de alimentos. 4th edn. Ministério da Saúde, Brasília. 